\title{
Mendongeng sebagai strategi pembelajaran karakter di TBM Nusa Bentang Saung Budaya Tatarkarang Cipatujah Tasikmalaya
}

\author{
Encang Saepudin', Ninis Agustini Damayani², Tine Silvana Rachmawati ${ }^{3}$ \\ 1,2,3Program Studi Ilmu Perpustakaan, Universitas Padjadjaran \\ Jl. Raya Bandung-Sumedang Km. 21, Jatinangor, Sumedang, Jawa Barat, 45363 \\ E-mail: ${ }^{1}$ encang@unpad.ac.id, ${ }^{2}$ ninis.agustini@unpad.ac.id, ${ }^{3}$ tine.silvana@unpad.ac.id
}

Received: December 2018; Accepted: December 2019; Published: December 2019

\begin{abstract}
Character education implementation must be integrated with various life activities. Storytelling activities can be a medium for character education, both at school and outside school. This is in line with the benefits of storytelling, namely to sharpen the imagination and thought, instill values and ethics, and improve vocabulary. This study aimed to find out the steps of storytelling as a character learning strategy. The research method used was a qualitative case study approach. The collecting data process was through interviews, discussions, observations, and literature studies. Validity and reliability tests were through the process of data triangulation and source triangulation. Consideration of choosing this method was the research data nature, which could maintain the object integrity. This means that data relating to research was comprehended as an integrated whole. Descriptive data analysis was through the stages of data reduction, data presentation, and concluding. Data sources in the study amounted to 7 people, consisting of community and religious leaders (3 people), manager of the 'Saung Budaya Tatarkarang' community reading park (2 people), and the education office (2 people). The results showed that storytelling activities at 'Saung Budaya Tatarkarang' were able to build children's character at the stages of socialization and internalization. This occurred due to the implementation of storytelling activities through the stages of setting goals and theme of the story, the form of storytelling, materials and tools, the design steps of storytelling activities, and the design of storytelling activities assessment. These five steps are carried out in stages in each event.
\end{abstract}

Keywords: Storytelling; Character learning; Character

\begin{abstract}
Abstrak
Pelaksanaan pendidikan karakter harus terintegrasi dengan berbagai aktivitas kehidupan. Aktivitas bercerita bisa menjadi media pendidikan karakter, baik di sekolah maupun di luar sekolah. Hal ini sejalan dengan manfaat dari bercerita yakni mengasah imajinasi dan daya pikir, menanamkan nilai dan etika, dan menambah perbendaharaan kata. Penelitian ini bertujuan mengetahui langkah-langkah mendongeng sebagai strategi pembelajaran karakter. Metode penelitian yang digunakan yaitu kualitatif pendekatan studi kasus. Proses pengumpulan data melalui wawancara, diskusi, observasi, dan studi pustaka uji validitas dan reliabilitas melalui proses triangulasi data dan triangulasi sumber. Pertimbangan pemilihan metode ini adalah sifat data penelitian mampu mempertahankan keutuhan dari objek. Hal ini berarti data yang berkaitan dengan penelitian dipahami sebagai satu kesatuan yang terintegrasi. Analisis data secara deskriptif melalui tahapan reduksi data, penyajian data, dan penarikan kesimpulan. Sumber data dalam penelitian berjumlah 7 orang dengan rincian; tokoh masyarakat dan agama ( 3 orang), pengelola taman bacaan masyarakat Saung Budaya Tatarkarang ( 2 orang), dan dinas pendidikan ( 2 orang). Hasil penelitian menunjukkan bahwa kegiatan bercerita di Saung Budaya Tatarkarang sudah bisa membangun karakter anak-anak pada tahapan sosialisasi dan internalisasi. Hal ini terjadi karena pelaksanaan kegiatan bercerita melalui tahapan penetapan tujuan dan tema cerita, bentuk bercerita, bahan dan alat, rancangan langkah-langkah kegiatan bercerita, dan rancangan penilaian kegiatan bercerita. Kelima langkah ini dilaksanakan secara bertahap dalam setiap kegiatan.
\end{abstract}

Kata Kunci: Mendongeng; Pembelajaran karakter; Karakter 


\section{PENDAHULUAN}

Membaca buku merupakan kegiatan utama dalam dunia pendidikan. Anakanak melalui membaca akan memperoleh pengetahuan baru, informasi, dan hiburan. Membaca merupakan proses berpikir yang mengandalkan gerakan mata dan cara kerja otak (Rachmayani, 2014). Membaca, lebih jauh memberikan peluang pada individu mengalami perubahan secara komprehensif. Kemampuan membaca seseorang menjadi titik penting dalam menjalankan kehidupan, baik dalam konteks spiritual, mental, ekonomi, sosial, budaya, dan politik. Selain itu Sudarsana (2014) dalam Aswani (2018) menjelaskan bahwa, "Membaca yaitu melihat serta memahami isi dari apa yang tertulis dengan melisankan atau hanya dalam hati."

Tantangan paling berat pada era teknologi saat ini, adalah pembiasaan membaca pada anak-anak. Sejak usia dini, mereka sudah terpapar teknologi komunikasi dan informasi. Masyarakat menghadapi kondisi saat ini, terutama orang tua sudah seharusnya mengenalkan aktivitas membaca. Keluarga yang cinta membaca akan memberikan dampak pada laju peningkatan kualitas sumber daya manusia. Salah satu cara merangsang gemar membaca ialah melalui mendongeng, bercerita, atau berkisah. Mendengarkan cerita merupakan salah satu usaha dalam meningkatkan keterampilan berbahasa, yang terdiri dari empat aspek, menyimak, berbicara, membaca, dan menulis (Sari \& Praherdhiono, 2014)

Sebuah studi yang dilaksanakan Hidayat (2014) mengungkapkan bahwa anak yang sejak dini dikenalkan pada buku dan kegiatan membaca akan memiliki tingkat keterbacaan yang tinggi.
Keterbacaan dan keterampilan berbahasa merupakan modal utama kemajuan bangsa. Anak-anak melalui mendongeng akan terbiasa menyerap pengetahuan dan memiliki pengalaman yang berbeda. Selain itu, anak-anak yang mendengarkan dongeng, akan diajarkan untuk memiliki rasa empati dan simpati terhadap sesama sehingga memiliki kepedulian sosial yang tinggi (Setiantono, 2012).

Menurut Pellowski (1997) dalam Paramitha, Kesiman, and Arthana (2014), mendongeng merupakan,

"Seni dari sebuah keterampilan bernarasi dalam bentuk syair dan prosa, yang dipertunjukkan dengan cara dinyanyikan, diceritakan, dengan atau tanpa musik, menggunakan alat peraga atau tanpa alat peraga, diperoleh dari sumber tercetak atau rekaman mekanik."

Mendongeng tidak hanya akan mengaktifkan sisi intelektual anak-anak, tetapi juga kepekaan, kehalusan budi, emosi, seni, daya fantasi, dan imajinasi. Ketika kita mendongeng, akan melibatkan otak kanan sehingga pesan yang disampaikan jauh lebih menghunjam di ingatan dibandingkan aktivitas nasihat yang menanamkan kognitif mengandalkan otak kiri.

"Ada berbagai konsep mendongeng yang dapat digunakan untuk mengajak anak membaca. Konsep mendongeng dan bermain, mendongeng sambil bermain musik, mengadakan festival mendongeng dengan konsep pementasan teater dari anak untuk anak, dan lain sebagainya. Dengan banyaknya konsep yang diusung, storyteller atau pencerita dapat menampilkan cerita secara menarik dan kreatif sehingga siswa tidak merasa bosan. Belajar sambil bermain 
adalah suatu hal yang tidak pernah lepas dari seorang anak. Hal inilah yang harus diingat oleh pencerita" (Bunanta, 2009).

Aktivitas bercerita bagi sebagian besar kalangan masih belum terasa penting. Terutama, di kalangan ekonomi menengah ke bawah sehingga urusan bacaan anak dan mendongeng belum mendapatkan perhatian. Hal tersebut terjadi karena keterbatasan pengetahuan masyarakat mengenai dampak positif dari mendongeng. Maka, untuk menyikapinya, perlu diadakan sosialisasi berkesinambungan supaya masyarakat dapat mengerti manfaat yang sangat besar dari bacaan anak dan mendongeng untuk masa depan anak-anak.

Anak-anak, pada rentang usia 0-12 tahun mengalami masa keemasan dalam menyerap informasi di sekitar lingkungannya (Akhriani, 2015). Pada tahap ini, anak-anak sebaiknya diberikan stimulasi bahasa dan kosakata yang banyak dan dikenalkan dengan nilai-nilai kehidupan. Mereka mendapatkan hal tersebut dari pola pengasuhan sehari-hari. Maka, pihak orang tua memiliki peran penting dalam membangun karakter anak melalui pengenalan nilai-nilai kehidupan.

Soetantyo (2013) melakukan penelitian mengenai peran dongeng dalam membentuk karakter anak. Menurutnya, dunia internet sudah menjadi gaya hidup para siswa. Hal ini terjadi karena arus informasi di dunia internet tidak bisa dibendung dan dikendalikan. Salah satu efek negatif dari derasnya arus informasi pada dunia internet yakni terjadinya kemerosotan moral. Untuk mengantisipasi semakin meluasnya pengaruh negatif ini, maka diperlukan pembinaan dan pendidikan karakter sejak dini. Pada prosesnya, pendidikan karakter kepada anak harus terintegrasi dengan berbagai aktivitas kehidupan, termasuk diintegrasikan dalam mata pelajaran di sekolah.

Strategi pendidikan karakter pada anak bisa dilakukan melalui tahapan sosialisasi, internalisasi, pembiasaan, dan pembudayaan (Soetantyo, 2013). Kegiatan mendongeng atau bercerita merupakan bagian dari budaya bangsa. Kita melalui mendongeng pada anak-anak, dapat mengenalkan karater tokoh yang baik dan tokoh yang jahat. Dengan demikian, mereka bisa mengetahui dan membandingkan kedua karakter tersebut. Adapun, "Anak-anak melalui bercerita/mendongeng bisa dikenalkan dengan karakter yang baik yang berkaitan dengan moral, sosial, maupun agama" (Soetantyo, 2013).

Selain itu, telah banyak penelitian mengenai kegiatan mendongeng sebagai media pendidikan karakter. Berdasarkan penelitian Fitroh and Sari (2015), ketika kita mendongeng akan terjadi proses transformasi nilai melalui perilaku dan karakter tokoh dalam cerita. Apalagi dalam kegiatan mendongeng, dibantu dengan media dan teknologi. Maka suasana mendongeng menjadi hidup, menarik dan akan terjadi komunikasi sosial antara anak dan guru/orang tua. Penyampaian cerita kepada anak harus dilakukan dengan benar agar karakter anak terbentuk dengan baik. Ketika kita menyampaikan cerita kepada anak, kita harus memperhatian segi penalaran melalui pemilihan kata dan kalimat yang benar. Hal ini terjadi karena saat penyampaian cerita, kita sedang "mengukir" atau "memahat" karakter anak. Fitroh and Sari (2015) kemudian menuturkan, bahwa, "Kita melalui metode bercerita pada anak-anak bisa memperoleh 
pesan moral secara langsung. Hal ini dapat membuat anak ingin meniru atau mencontoh karakter yang ada di dalam cerita tersebut." Anak-anak dapat berimajinasi melalui melihat langsung gambar dari contoh karakter yang baik.

Selanjutnya, penelitian berikutnya dilaksanakan Habsari (2017) menjelaskan bahwa dalam dongeng mengandung nilainilai moral dan nilai sosial yang sangat bermanfaat bagi pembangunan karakter anak. Selain itu, dongeng dapat bermanfaat untuk mengasah emosi, melatih imajinasi, dan dapat meningkatkan daya kritis anak. Apalagi, mendongeng pada anak merupakan usaha untuk mendorong terbentuknya karakter anak melalui pemberian contoh dan ilustrasi. Hal ini merupakan sebuah strategi pembentukan karakter yang mudah dilakukan. Selain itu, Habsari (2017) juga menyebutkan bahwa strategi pembentukan karakter anak bisa dilakukan melalui pemberian contoh, pembiasaan membaca dongeng, pembiasaan mendengarkan dongeng, dan menciptakan lingkungan yang gemar membaca.

"Pembentukan karakter melalui dongeng di lingkungan sekolah bisa melalui pembiasaan siswa melalui membaca dongeng secara mandiri satu minggu sekali. Guru membacakan dongeng yang menarik bagi siswa satu minggu sekali. Kemudian siswa mencatat nilai-nilai moral dan sosial yang terdapat dalam cerita, dan siswa membuat ringkasan cerita" (Habsari, 2017).

Dongeng pun dapat menjadi sarana yang tepat untuk membangun karakter yang baik pada diri anak-anak karena mereka akan menerima pesan moral dan sosial dengan senang hati (Soetantyo,
2013). Anak-anak akan belajar mengenai nilai-nilai kehidupan tanpa merasa diajari. Soetantyo (2013) menambahkan bahwa untuk menanamkan nilai moral dan sosial dalam cerita, anak-anak dapat mencoba bermain peran mengenai tokoh dalam cerita. Ketika anak-anak bermain peran, mereka akan lebih menjiwai cerita, terutama karakter dari masing-masing tokoh.

Pendidikan karakter kepada anak memang harus terintegrasi dalam berbagai aktivitas kehidupan, termasuk diintegrasikan dalam pendidikan di luar sekolah. Kegiatan bercerita bisa menjadi media pendidikan karakter baik di sekolah maupun di luar sekolah. Anak-anak melalui mendongeng, dapat dikenalkan pada karakter yang baik, yakni berkaitan dengan moral, sosial, maupun agama. Selain itu, kegiatan mendongeng dapat meningkatkan daya imajinasi, kemampuan berbahasa, dan kognitif anak. Hal ini sejalan dengan penelitian Pebriana (2017), yang menyatakan bahwa, "Pada saat anak menyimak cerita yang disampaikan maka terjadi proses tranformasi nilai moral dan sosial melalui karakter tokoh dalam cerita." Dengan demikian, melalui proses mendengarkan cerita (mendongeng) akan terjadi perubahan pengetahuan, pemahaman, sikap, bahkan perilaku pada diri anak. Hal ini karena pesan dalam cerita dapat memengaruhi kemampuan emosi, imajinasi, dan perilaku anak.

Berdasarkan latar belakang tersebut, penelitian ini bertujuan untuk mengetahui kegiatan mendongeng sebagai strategi pembelajaran karakter yang dilaksanakan di Taman Bacaan Masyarakat Saung Budaya Tatarkarang Cipatujah Kabupaten Tasikmalaya. Secara rinci penelitian ini akan menggali mengenai langkah-langkah 
mendongeng sebagai strategi dalam pendidikan karakter dan nilai-nilai kehidupan yang tertanam dalam diri anakanak.

\section{METODE PENELITIAN}

Metode yang digunakan dalam penelitian ini yaitu kualitatif melalui pendekatan studi kasus. Studi kasus bersifat eksploratif dan deskriptif. Metode ini dipandang efektif karena mampu mencari motif dibalik fakta sosial yang tampak secara empiris. Penelitian studi kasus memfokuskan pada penelitian dengan cara merinci data mengenai suatu objek selama kurun waktu tertentu dengan cukup mendalam dan menyeluruh. Selain itu, pertimbangan pemilihan pendekatan ini yaitu sifat data penelitian mampu mempertahankan keutuhan dari objek. Hal ini berarti data yang berkaitan dengan penelitian dipahami sebagai satu kesatuan yang terintegrasi. Dengan demikian pemaparan data akan sesuai dengan fakta di lapangan (Rahardjo, 2017).

Sumber data dalam penelitian ini berjumlah 7 orang dengan rincian sebagai berikut, tokoh masyarakat dan agama (3 orang), pengelola Taman Bacaan Masyarakat Saung Budaya Tatarkarang (2 orang), dan dinas pendidikan (2 orang). Mereka berperan sebagai informan dalam memahami pokok permasalahan, sedangkan yang menjadi objek penelitian yakni pendidikan karakter. Proses pengumpulan data penelitian melalui wawancara, diskusi, observasi, dan studi pustaka. Proses uji validitas dan reliabilitas dilakukan melalui triangulasi data dan triangulasi sumber. Analisis data secara deskriptif melalui tahapan reduksi, penyajian, penarikan kesimpulan \& verifikasi (Rahardjo, 2017).

\section{HASIL DAN PEMBAHASAN}

Pengasuhan anak dalam kehidupan sehari-hari tidak cukup jika hanya mengandalkan kemampuan perawatan sederhana. Anak-anak perlu mendapatkan bimbingan akhlak dan bimbingan dalam tumbuh kembangnya secara utuh dan berkelanjutan. Proses bimbingan dalam tumbuh kembang anak diarahkan untuk meningkatkan kemampuan kognitif, afektif, dan psikomotoriknya secara berkelanjutan. Agar proses tumbuh kembang anak dapat tercapai maka para orang tua dan guru harus memiliki kemampuan yang cukup dalam mendampingi anak. Oleh karena itu, keterbukaan akses terhadap informasi sangat diperlukan. Hal ini memiliki arti bahwa para orang tua dan guru harus melek informasi mengenai tumbuh kembang anak yang baik dan efektif.

Jika orang tua dan guru memiliki keterbatasan dalam mengakses informasi mengenai tumbuh kembang anak, maka bisa dipastikan jiwa anak akan gersang yang disebabkan oleh hausnya informasi. Anak-anak yang berpikiran kritis tentu menuntut ragam jawaban yang akan memuaskan dahaga pengetahuannya. Seperti kita ketahui bahwa pada masa perkembangannya anak-anak selalu diikuti oleh pertanyaan-pertanyaan yang muncul dari rasa keingintahuaan anak terhadap lingkungan sekitarnya. Rasa penasaran dan keingintahuan anak harus dibimbing dan diarahkan para orang tua dan guru, sehingga rasa penasaran itu dapat terbangun menjadi daya kritis pada jiwa anak yang dilandasi nilai dan norma kehidupan.

Untuk melaksanakan hal tersebut, timbul sebuah pertanyaan. Bagaimana agar guru dan orang tua dapat menanamkan nilai-nilai kehidupan yang 
baik pada anak dengan cara yang menyenangkan tanpa menggurui? Bagaimana kita bisa menjadi sumber informasi yang baik untuk anak-anak? Jawaban terhadap pertanyaan tersebut adalah mendongeng dan bercerita. Mendongeng dan bercerita bila dijadikan bagian dari kegiatan sehari-hari dalam membentuk kepribadian anak agar memiliki kecerdasan emosional dan intelektual bahkan kecerdasan spiritual. Kegiatan bercerita akan mendorong anakanak belajar tanpa proses diajari. Hal ini berarti mereka memperoleh pengetahuan bahkan terjadi perubahan perilaku tanpa mereka sadari.

Hal tersebut bisa kita lihat ketika anakanak mendengarkan cerita kepahlawanan. Pada saat mereka mengikuti proses bercerita, mereka menyimak dan memahami karakter tokoh kepahlawanan tersebut. Setelah selesai bercerita, mereka memiliki kecenderungan untuk menjadi seorang pahlawan yang memiliki karakter pemberani, jujur, dan rela berkorban. Hal ini menggambarkan bahwa melalui proses bercerita anak-anak itu belajar tanpa merasa diajari.

Namun, pada masa sekarang kegiatan mendongeng dan bercerita tidak menjadi kegiatan rutin bahkan sebagian orang sudah meninggalkannya. Hal ini terjadi karena para orang tua tidak memiliki waktu yang cukup untuk bisa bersama dengan anak-anaknya. Dengan demikian, sebagian orang menganggap bercerita merupakan kegiatan yang merepotkan.

Survei yang dilaksanakan Disney (2010) yang dikutip Wolipop.detik.com (2012) menggambarkan bahwa di Inggris hanya satu per-tiga para orang tua yang masih membacakan cerita untuk anaknya menjelang tidur. Survei diikuti 1000 orang tua yang memiliki anak atau cucu berusia di bawah enam tahun. Hasil survey menggambarkan bahwa dua pertiga dari orang tua merasa bahwa teknologi modern sudah menghilangkan tradisi mendongeng.

Kegiatan mendongeng dan bercerita sebenarnya kegiatan yang sangat positif. Kegiatan ini selain memiliki manfaat untuk meningkatkan daya imajinasi, kemampuan berbahasa, dan kognitif anak, juga dapat mempererat hubungan orang tua dengan anak (Pertiwi, 2011). Mendongeng bukan semata-mata kegiatan untuk menidurkan anak, namun berfungsi sebagai jembatan penghubung kedekatan antara anak dan orang tua. Membacakan cerita secara tidak langsung membangun komunikasi antara orang tua dengan anak. Anak akan memperoleh pesan lewat cara yang menyenangkan, maka dia akan menyerap pesan tersebut tanpa merasa digurui apalagi dipaksa. Apalagi aktivitas bercerita ini melibatkan otak kanan, yang memori penyimpanannya lebih panjang tertanam dalam otak manusia.

Membacakan buku cerita kepada anak, memiliki arti bahwa orang tua sedang menghibur, menjalin ikatan, memberikan informasi, dan menginspirasi kepada anak. Pada saat orang tua membacakan cerita kepada anak, mereka akan merasa senang karena mendapat perhatian dari orang tua. Mereka terhibur oleh dua hal secara bersamaan yakni oleh isi cerita dan perhatian lebih dari orang tua sehingga terjalin ikatan yang lebih kuat antara keduanya. Di samping itu, melalui isi cerita yang disampaikan, anak-anak mendapat informasi (terjadi proses pembelajaran yang tidak disadari) mengenai nilai-nilai kehidupan. Pesanpesan moral yang ada dalam isi cerita dapat diserap dan disimpan dalam alam pikiran anak. 
Hal ini sesuai pendapat Trelease (2008) dalam Zikri (2016) yang menyatakan bahwa bila orang tua bercerita dengan suara lantang, berarti telah mengondisikan otak anak untuk mengasosiasikan membaca dengan kebahagiaan, menciptakan informasi yang berfungsi sebagai latar belakang, membangun kosakata, dan memberikan teladan gemar membaca. Hal ini dikuatkan pula pendapat Puspita (2009) dalam Cendana (2010) yang menyatakan bahwa, "Manfaat dari mendongeng dan bercerita yakni mengasah imajinasi dan daya pikir anak, mempererat ikatan komunikasi antara pencerita dan pendengar, menanamkan nilai dan etika pada diri anak, dan menambah perbendaharaan kata pada anak."

Berdasarkan ulasan di atas, mendongeng bisa menjadi sebuah strategi pembelajaran kepada anak. Strategi pembelajaran merupakan segala usaha guru dalam menerapkan berbagai metode pembelajaran untuk mencapai tujuan yang diharapkan. Hal ini sejalan pendapat Masitoh (2007) dalam Eliwarti (2016) yang menulis bahwa, "Dalam strategi pembelajaran adalah pola umum perbuatan guru dan murid dalam perwujudan kegiatan belajar mengajar." Dengan demikian, strategi pembelajaran menekankan kepada bagaimana aktivitas guru mengajar dan aktivitas anak belajar dalam mencapai tujuan pembelajaran secara tepat dan efektif.

Bercerita sebagai sebuah metode pembelajaran yang memiliki daya tarik menyentuh perasaan. Hal ini terjadi karena dalam bercerita melibatkan suasana dengan kandungan pesan moral. Bercerita merupakan seni atau teknik budaya kuno untuk menyampaikan suatu peristiwa yang dianggap penting, melalui kata-kata, imajinasi, dan suara-suara (Amanah, 2015).

Penggunaan bercerita sebagai strategi pembelajaran sebaiknya memperhatikan unsur isi cerita dan kegiatan bercerita. Pemilihan isi cerita harus berhubungan dengan dunia kehidupan anak. Hal ini dilakukan agar anak bisa mengembangkan daya imajinasi, karena apa yang diceritakan berkaitan dengan pengalaman hidupnya. Kegiatan bercerita harus memberikan perasaan gembira, senang, lucu, dan menyenangkan. Hal ini sesuai dunia anak yang penuh keceriaan dan kegembiraan. Selain itu, kegiatan bercerita harus memberikan pengalaman unik dan menarik sehingga hal ini akan tertahan dalam pikiran anak-anak.

Kegiatan bercerita sebagai strategi pembelajaran dapat membantu anak-anak dalam mencapai tujuan pembelajaran. Selain itu, bercerita bermanfaat bagi perkembangan anak-anak secara kognitif dan afektif. Dengan demikian, kegiatan bercerita dapat membantu tercapainya tujuan pendidikan. Guru terlebih dahulu harus menetapkan tujuan dan tema cerita sebelum melaksanakan kegiatan bercerita. Hal ini menjadi acuan kegiatan sekaligus sebagai ukuran pencapaian tujuan pembelajaran melalui bercerita. Pada saat menetapkan tujuan dan tema bercerita, guru memiliki kebebasan dengan catatan guru memiliki kemampuan dalam menggambarkan dan mengembangkan isi cerita. Selain itu, tema yang dipilih harus menunjang terhadap pencapaian tujuan pendidikan.

Sebagai gambaran dalam merancang bercerita sebagai metode pembelajaran Masitoh (2007) dalam Laily and Andajani (2014) menetapkan lima langkah bercerita, di antaranya menentukan tujuan dan tema cerita, bentuk bercerita, bahan dan alat, 
rancangan langkah-langkah kegiatan bercerita, dan rancangan penilaian kegiatan bercerita. Hal pertama yang harus dilakukan pencerita adalah menetapkan tujuan dan tema cerita. Pemilihan tema cerita yang akan disampaikan harus diselaraskan dengan tujuan pembelajaran. Hal ini harus dilakukan agar perubahan sikap dan tingkah laku anak sebagai hasil pembelajaran dapat tercapai. Pada dasarnya tujuan pembelajaran yakni terjadinya perubahan pengetahuan, sikap, dan tingkah laku pada peserta didik.

Seperti kita ketahui bahwa anak-anak adalah peniru yang luar biasa. Anak-anak akan meniru dari apa yang didengar, dilihat, dan dirasakan dan menyimpannya dalam alam pikiran. Kata lain, pesan dari cerita yang disampaikan menjadi informasi yang tersimpan di alam bawah sadar berupa pesan baik atau buruk. Oleh karena itu, informasi tersebut akan selalu diingat dan menjadi referensi buat dirinya sendiri dalam berperilaku sehari-hari.

Dengan demikian, ketika memilih tema cerita, kita harus berhati-hati dan teliti. Adapun, tema yang disuguhkan harus syarat dengan pesan moral yang bisa membimbing tumbuh kembang anak ke arah yang lebih baik, contohnya cerita yang menggambarkan keteladanan dan nilai moral dalam kehidupan. Maka, kita berusaha menghindari tema yang menggambarkan kekerasan, permusuhan, dan lain-lain.

Buku cerita yang sering digunakan sebagai bahan dalam proses bercerita di Taman Bacaan Saung Budaya Tatarkarang, yakni kisah-kisan para nabi, cerita sejarah, dan cerita anak-anak. Hal ini dipilih dengan pertimbangan isi buku cerita menggambarkan keteladanan, patriotisme, persahabatan, kejujuran, dan tanggung jawab. Pihak pengelola taman bacaan masyarakat menyatakan bahwa,

“Orientasi pembelajaran di taman bacaan masyarakat adalah membangun kepribadian anak-anak yang jujur, bertanggung jawab, dan mandiri. Oleh karena itu, cerita yang dipilih adalah cerita yang mengandung unsur pesan mengenai hal tersebut" (Awangga, wawancara, August 11, 2018).

Hal kedua, pencerita dapat menetapkan bentuk bercerita, yang disampaikan selaras dengan kondisi pengalaman hidup anak-anak agar anak bisa menjiwai seluruh jalan cerita. Hal ini agar pesan dari penulis dapat diterima dan lebih tertanam pada jiwa anak-anak. Bentuk bercerita bisa berupa membacakan cerita langsung dari buku, menggunakan buku cerita bergambar, menggunakan boneka sebagai alat bantu bercerita, dan bermain peran berdasarkan isi cerita. Bentuk bercerita yang sering dilakukan pihak Taman Bacaan Saung Budaya Tatarkarang adalah pembacaan buku cerita bergambar dan bermain peran. Kedua bentuk bercerita ini dipilih dengan pertimbangan pembacaan buku cerita bergambar memiliki daya tarik lebih kuat bila dibandingkan dengan buku cerita tanpa disertai gambar. Jadi, buku tersebut memiliki deskripsi cerita dan gambar yang memperkuat atau mengilustrasikan isi cerita.

Anak-anak dapat mencermati isi bahkan memahami isi cerita melalui gambar dalam buku. Hal ini terlihat dari kemampuan anak-anak dalam menceritakan kembali isi cerita melalui gambar. Kondisi ini sesuai dengan pendapatnya Yustina (2011) dalam Subhanadri and Indriyani (2018) mengenai kelebihan media gambar, di antaranya (1) 
sifatnya konkret, gambar lebih realistis menunjukkan pokok masalah dibandingkan dengan media verbal semata, (2) gambar dapat mengatasi batasan ruang dan waktu, (3) gambar dapat mengatasi keterbatasan pengamatan, (4) dapat memperjelas suatu masalah, dapat menghindari salah paham, dan (5) biayanya terjangkau dan gampang didapatkan serta digunakan.

Pemilihan bentuk cerita melalui bermain peran dipilih melalui pertimbangan bahwa anak-anak yang bermain peran bisa lebih menjiwai isi cerita, melalui keaktifan sebagai tokoh. Pada saat bermain peran, karakter tokoh dalam cerita adanya internalisasi dalam diri anak-anak. Dengan demikian, anakanak menjiwai karakter tersebut sangat mendalam.

Pada pelaksanaan kedua bentuk cerita ini dilaksanakan secara berurutan, yaitu dimulai dari anak-anak mendengarkan cerita yang dibacakan, lalu menceritakan kembali isi cerita melalui gambar dalam buku, dan memainkan peran tokoh cerita dalam bentuk drama singkat. Sesuai langkah-langkah tersebut, maka anak-anak yang menjiwai karakter tokoh cerita dapat terlihat dalam sikap dan perilaku seharihari.

Langkah-langkah tersebut tergambar dari hasil wawancara dengan pengelola Saung Budaya Tatarkarang. Narasumber menyatakan bahwa,

"Agar anak-anak lebih bisa menghayati isi cerita mereka harus mengikuti tiga langkah bercerita secara berkesinambungan. Ketiga langkah tersebut adalah menyimak isi cerita, menceritakan kembali, dan memerankan isi cerita" (Awangga, wawancara, 11 August, 2018).

Maka, ketepatan pemilihan bentuk cerita akan memengaruhi ketertarikan anak-anak dalam menyerap informasi yang disampaikan. Oleh karena itu, pencerita sebelum menentukan bentuk cerita yang dipilih harus memahami dahulu kondisi calon pendengar. Bentuk cerita dipilih di taman bacaan masyarakat Saung Budaya Tatarkarang adalah buku cerita bergambar. Hal ini dilakukan dengan pertimbangan bahwa buku cerita bergambar akan membantu pemahaman anak terhadap isi cerita. Gambar dalam buku cerita dapat menjadi visualisasi dari cerita. Adanya bantuan gambar, anak dapat mudah mencerna pesan yang disampaikan.

Mereka akan lebih fokus dan bersemangat dalam mengikuti kegiatan bercerita bila si pencerita dapat mengikuti kesukaan dan ketertarikan mereka. Di samping itu, mereka menjadi lebih menyukai buku yang diceritakan, terlihat dari respon mereka ketika selesai proses bercerita. Mereka ingin melihat langsung gambar dalam buku. Hal ini ditegaskan oleh pernyataan dari pengelola Saung Budaya Tatarkarang bahwa, "Anak-anak lebih suka dibacakan cerita buku bergambar. Dengan melihat gambar, mereka bisa membayangkan apa yang terjadi dalam peristiwa tersebut" (Sukmana, wawancara, September 7, 2018).

Hal yang ketiga adalah menetapkan sarana pendukung bercerita. Pemilihan sarana sangat terkait erat dengan penetapan bentuk bercerita dan tema cerita yang dipilih, contohnya pencerita memilih tema cerita binatang dengan penyampaian cerita menggunakan boneka. Untuk mendukung pelaksanaan cerita ini, maka diperlukan berbagai boneka binatang untuk menggambarkan karakter dari setiap tokoh yang akan 
diceritakan. Boneka binatang dalam cerita ini menjadi visualisasi dari karakter setiap tokoh yang diperankan.

Pemilihan sarana pendukung cerita yang disiapkan Pengelola Saung Budaya Tatarkarang masih sangat sederhana. Hal ini karena masih terbatasnya sarana yang dimiliki. Oleh karena itu, pemilihan buku cerita bergambar menjadi pilih yang paling tepat. Selain itu, gambar dalam buku cerita membuat anak-anak tetap bisa memvisualkan isi cerita dengan baik. Bahkan mereka bisa berimajinasi mengenai isi gambar tersebut dengan tidak terbatas.

Hal keempat dalam tahapan persiapan bercerita sebagai proses pembelajaran adalah menyusun langkah-langkah bercerita. Langkah-langkah ini dimulai dari menyampaikan tujuan dan tema cerita, menata tempat duduk untuk anakanak, menyampaikan cerita, dan mengevaluasi kegiatan bercerita. Secara rinci langkah bercerita dapat digambarkan sebagai berikut. Pertama, tujuan bercerita kepada anak adalah menanamkan nilainilai sosial, moral, dan agama. Oleh karena itu, pada awal bercerita guru/pencerita harus menyampikan tujuan utama dari penyampaian tema cerita. Nilai-nilai apa saja yang bisa diserap dari cerita yang akan disampaikan harus diketahui terlebih dahulu oleh anak-anak. Dengan demikian, anak-anak selama proses bercerita bisa ikut mencermati jalan cerita dan mengidentifikasi alur cerita bagian mana yang mengandung pesan tersebut. Penyampaian tujuan pada saat pembukaan cerita merupakan sebuah usaha si pencerita untuk melibatkan peserta.

Kedua, metode bercerita sebaiknya dilaksanakan pada kelompok kecil. Proses bercerita pada kelompok kecil akan berjalan lebih efektif, karena pencerita akan lebih mudah mengontrol keberlangsungan kegiatan. Kegiatan dalam kelompok kecil akan memudahkan pengaturan tempat duduk peserta, sehingga semua peserta bisa nyaman, fokus, dan terjalin komunikasi yang efektif dengan pencerita. Pelaksanaan bercerita di lingkungan Saung Budaya Tatarkarang sering menggunakan metode kelompok cukup besar antara 20-30 orang. Pemilihan ini didasarkan kepada pertimbangan anak-anak yang sering mengikuti acara ini cukup banyak yakni 30 orang. Dengan demikian, anak-anak dibuat dalam satu kelompok dan dilaksanakan setiap hari Minggu sore.

Pemilihan kelompok besar memang memiliki kendala yakni sulitnya mengondisikan anak, penataan tempat duduk, dan perhatian anak mudah terganggu. Hal ini ditegaskan Pengelola Saung Budaya Tatarkarang bahwa, "Dengan banyaknya anak-anak yang mengikuti acara mendongeng ini, akan menemui kesulitan yakni penataan tempat, perlu ada pengeras suara, dan anak-anak sering rebutan" (Awangga, wawancara, September 7, 2018).

Ketiga, pembukaan dalam bercerita merupakan daya pikat terkuat dari alur cerita yang akan disuguhkan. Oleh karena itu, si pencerita harus mampu menyuguhkan sesuatu yang fantastik pada saat membuka sebuah cerita, misalnya dimulai suara dentuman, musik yang menggebrak, atau teriakan dari tokoh cerita. Hal ini dilakukan untuk menarik perhatian sekaligus membuka arus komunikasi dengan peserta.

Lingkungan masyarakat di sekitar Saung Budaya Tatarkarang adalah masyarakat yang religius. Oleh karena itu, anak-anak yang sering mengikuti acara ini 
adalah anak-anak yang harus dibangun karakter religius. Pembuka cerita sebagai gerbang untuk membangun cerita selalu dimulai melalui doa bersama. Hal ini diyakini bahwa sesuatu yang baik harus diawali hal yang baik.

Proses pengembangan cerita memerlukan daya imajinasi yang sangat kuat. Seorang pencerita akan berhasil menyuguhkan daya tarik cerita bila mampu mengilustrasikan isi cerita melalui ujaran dan gerak. Pada umumnya cerita dalam dongeng bersifat fiktif, sehingga alur dalam cerita akan mampu mendorong daya fantasi anak. Anak-anak melalui mendengarkan dongeng akan memiliki daya fantasi yang berkembang sesuai alur cerita. Setelah itu, unsur pendidikan tentang nilai moral, sosial, dan agama bisa ditanamkan ke dalam benak anak.

Penanaman nilai-nilai ini bisa ditegaskan pada karakter tokoh dalam cerita. Pada cerita rakyat, karakter tokoh baik dan tokoh jahat disandingkan secara hitam putih. Dengan demikian, anak-anak secara mudah dapat mencerna sifat tokoh dalam cerita. Karakter yang bersifat tokoh baik, digambarkan memiliki sifat jujur, adil, penuh cinta kasih, penyabar dan lain sebagainya. Adapun karakter tokoh jahat digambarkan memiliki sifat tamak, mudah marah, sombong, dan lain sebagainya. Pada umumnya, konflik tokoh jahat dan tokoh baik akan berakhir dengan kemenangan dari tokoh baik. Sesuai suguhan konflik ini, anak-anak akan bisa mencerna nilai-nailai luhur dari sebuah cerita.

Keempat, pada akhir cerita, peserta harus diminta tanggapan mengenai pesanpesan moral, sosial, atau agama yang bisa mereka cerna selama proses bercerita. Tanggapan anak-anak terhadap cerita yang disampaikan dapat menjadi gambaran keberhasilan sebuah kegiatan bahkan bisa menjadi umpan balik yang bernilai positif. Tanggapan mereka bisa menjadi gambaran atas capaian dari tujuan bercerita yang telah ditetapkan sedari awal.

Kelima, dalam tahapan persiapan bercerita sebagai proses pembelajaran, yaitu menyusun rancangan penilaian kegiatan bercerita. Unsur dalam penilaian pelaksanaan kegiatan bercerita harus menyesuaikan berdasarkan tujuan yang ditetapkan di awal kegiatan. Hasil penilaian bisa dijadikan bahan evaluasi dalam meningkatkan kualitas pelaksanaan kegiatan bercerita di tahapan berikutnya. Rancangan penilaian kegiatan bercerita disusun sebagai acuan dan ukuran ketercapaian dari tujuan kegiatan. Selain itu, rancangan penilaian bisa digunakan sebagai pedoman pencerita sehingga si pencerita bisa mengarahkan peserta didik untuk menunjukkan penguasaan kompetensi yang telah ditetapkan.

\section{SIMPULAN}

Bercerita sebagai strategi pembelajaran karakter memiliki lima langkah di antaranya, menetapkan tujuan dan tema cerita, bentuk bercerita, bahan dan alat, rancangan langkah-langkah kegiatan bercerita, dan rancangan penilaian kegiatan bercerita. Kegiatan mendongeng sebagai strategi pembelajaran karakter berada pada tahapan sosialisasi dan internalisasi. Hal ini berarti terjadi penanaman nilai-nilai kehidupan dalam diri anak-anak. Kegiatan mendongeng dapat meningkatkan daya imajinasi, kemampuan berbahasa, kognitif anak, dan mengeratkan hubungan pihak pencerita dengan pendengarnya. Peneliti berharap hasil penelitian ini bisa dijadikan rujukan untuk penelitian lebih lanjut mengenai 
pola pendidikan karakter anak usia dini atau peran taman bacaan masyarakat sebagai media pembelajaran sepanjang hayat.

\section{DAFTAR PUSTAKA}

Akhriani, H. N. (2015). Hubungan pola asuh orang tua dengan perkembangan anak pra sekolah di pendidikan anak usia dini 'Aisyiyah Insan Robbani Muntilan (Skripsi) (Universitas 'Aisyiyah Yogyakarta (UNISA), Yogyakarta). Retrieved from http:/ / digilib.unisayogya.ac.id/529/ 1/NASKAH PUBLIKASI HERLINA NINDI A 201410104054.pdf

Amanah, N. (2015). Pengembangan kemampuan berbicara melalui kegiatan bercerita dengan boneka jari pada anak usia 5-6 tahun di PAUD Al-Hikmah Gotong Royong tahun pelajaran 2014/2015 (Skripsi) (Universitas Mataram, Mataram). Retrieved from http:/ / eprints.unram.ac.id/6470/1/J URNAL.doc

Aswani. (2018). Pengaruh motivasi belajar dan penguasaan tata bahasa terhadap pemahaman membaca teks eksplanasi bahasa Indonesia siswa SMA Negeri. Diskursus: Jurnal Pendidikan Bahasa Indonesia, 1(1), 11-22. Retrieved from https://journal.lppmunindra.ac.id/in dex.php/diskursus/article/view/350 8/2409

Bunanta, M. (2009). Buku, mendongeng dan minat membaca. Retrieved from https:/ / scholar.google.co.id/scholar? $\mathrm{hl}=\mathrm{id} \& a s \_s d \mathrm{t}=0 \% 2 \mathrm{C} 5 \& \mathrm{q}=$ Bunanta $\% 2$ C+Murti.+\%282009\%29.+Buku \%2C+ Dongeng $\% 2 \mathrm{C}+$ dan + Minat + Baca $\% 2 C$ \&btnG $=$

Cendana, R. (2010). Peningkatan pembelajaran apresiasi dongeng dengan media visual manipulatif boneka pada siswa kelas VII SMP Muhammadiyah 1 Gatak, Sukoharjo tahun ajar 2009/2010 (Skripsi) (Universitas

Muhammadiyah Surakarta, Surakarta). Retrieved from http:/ / eprints.ums.ac.id/8434/1/A31 0060035.pdf

Eliwarti. (2016). Penerapan strategi penemuan terbimbing untuk meningkatan kemampuan kognitif anak usia 5-6 tahun di Tk Amal Ikhlas Rumbai Pekanbaru. Primary: Jurnal Pendidikan Guru Sekolah Dasar, 5(1), 130-140.

https://doi.org/10.33578/jpfkip.v5i1. 3688

Fitroh, S. F., \& Sari, E. D. N. (2015). Dongeng sebagai media penanaman karakter pada anak usia dini. Jurnal PG-PAUD Trunojoyo: Jurnal Pendidikan Dan Pembelajaran Anak Usia Dini, 2(2), 95-105.

https://doi.org/10.21107/jpgpaud.v2 i2.2606

Habsari, Z. (2017). Dongeng sebagai pembentuk karakter anak. BIBLIOTIKA: Jurnal Kajian Perpustakaan Dan Informasi, 1(1), 2129. Retrieved from http://journal2.um.ac.id/index.php/ bibliotika/article/view/703/438

Hidayat, A. (2014). Analisis keterbacaan buku dwibahasa seri mengenal hewan: Cerita si laba-laba. Wanastra: Jurnal Bahasa Dan Sastra, 6(2), 11-18. https://doi.org/10.31294/w.v6i2.382 9

Laily, L. I., \& Andajani, S. J. (2014). Pengaruh metode cerita bermedia gambar seri terhadap kemampuan berbicara anak kelompok B di TK Muslimat Nu 38. PAUD Teratai, 3(3), 1-7. Retrieved from https:/ /jurnalmahasiswa.unesa.ac.id 
/index.php/paud-

teratai/article/view/7537/3687

Paramitha, A. A. I. I., Kesiman, M. W. A., \& Arthana, I. K. R. (2014). Pengembangan "digital interactive storyteller" berbasis android untuk tunanetra. Jurnal Nasional Pendidikan Teknik Informatika (JANAPATI), 3(3), 142-149.

https://doi.org/10.23887/janapati.v3 i3.9824

Pebriana, P. H. (2017). Analisis kemampuan berbahasa dan penanaman moral pada anak usia dini melalui metode mendongeng. Jurnal Obsesi: Jurnal Pendidikan Anak Usia Dini, 1(2),

139-147. https:// doi.org/10.31004/obsesi.v1i2. 34

Pertiwi, A. R. (2011). Peningkatan minat membaca dalam pembelajaran bahasa Indonesia melalui metode mendongeng (story telling) pada Siswa kelas IV SD Negeri Pabelan 02 Kartasura Kabupaten Sukoharjo tahun ajaran 2010/2011 (Skripsi) (Universitas Sebelas Maret, Surakarta). Retrieved from https://core.ac.uk/download/pdf/1 2350013.pdf

Rachmayani, D. (2014). Penerapan pembelajaran reciprocal teaching untuk meningkatkan kemampuan komunikasi matematis dan kemandirian belajar matematika siswa. JUDIKA (Jurnal Pendidikan Unsika), 2(1), 13-23. Retrieved from https://journal.unsika.ac.id/index.ph $\mathrm{p} / \mathrm{judika/article/view/118/122}$

Rahardjo, M. (2017). Studi kasus dalam penelitian kualitatif: Konsep dan prosedurnya. Retrieved February 3, 2019, from Research Repository Universitas Islam Negeri Maulana Malik Ibrahim Malang website: http://repository.uinmalang.ac.id/1104/1/Studi-kasusdalam-penelitian-kualitatif.pdf

Sari, P. N. P., \& Praherdhiono, H. (2014). Pengaruh penggunaan metode maternal reflektif terhadap keterampilan membaca permulaan Siswa Tunarungu Kelas III SDLB. Jurnal Ortopedagogia, 1(3), 217-224. Retrieved from http://journal2.um.ac.id/index.php/j o/article/view/4614/2533

Setiantono, T. (2012). Penggunaan metode bercerita bagi anak usia dini di PAUD Smart Little Cilame Indah Bandung. Empowerment: Jurnal Ilmiah Program Studi Pendidikan Luar Sekolah, 1(2), 1823.

https://doi.org/10.22460/empowerm ent.v1i2p18-23.611

Soetantyo, S. P. (2013). Peranan dongeng dalam pembentukan karakter siswa sekolah dasar. Jurnal Pendidikan, 14(1), 44-51. Retrieved from http://ilp.ut.ac.id/index.php/JP/arti cle/view/165/132

Subhanadri, \& Indriyani, R. (2018). Upaya meningkatkan proses dan hasil belajar siswa dengan menggunakan metode picture and picture dalam pembelajaran IPA Kelas III SDN 105/II Desa Rambah. Jurnal Tunas Pendidikan, 1(1), 1-10. Retrieved from http://ejournal.stkipmmb.ac.id/index.php/pgsd/article/ view/68/21

Wolipop.detik.com. (2012). Hanya 33\% orangtua yang masih sempat mendongeng untuk anak. Retrieved from https://wolipop.detik.com website:

https://wolipop.detik.com/read/ 2012/10/10/070850/2058848/857/ha nya-33-orang tua -yang-masih- 
sempat-mendongeng-untuk-anak

Zikri, R. (2016). Peran orang tua dalam mengoptimalkan perkembangan bahasa anak fase golden age. Al-Lisan: Jurnal Bahasa, 1(2), 109-130. Retrieved from

http://www.journal.iaingorontalo.ac. id/index.php/al/article/view/323/2 78 